\title{
Apigenin Ameliorates Lead Acetate induced Hyperlipidemia, Hypothyroidism and Hypogonadism in Male Rats
}

\author{
Abdulmohsen Algefare \\ King Faisal University College of Science \\ Azza Mahmoud Sedky ( $\nabla$ salma_haidy@yahoo.com ) \\ King Faisal University \\ Manal Alfwuaires \\ King Faisal University College of Science \\ omar mahmoud \\ specialty general adult psychiatry registrar
}

\section{Research Article}

Keywords: testis, thyroid gland, lipid profile, lead, apigenin

Posted Date: July 26th, 2021

DOl: https://doi.org/10.21203/rs.3.rs-600247/v1

License: (c) (i) This work is licensed under a Creative Commons Attribution 4.0 International License. Read Full License 


\section{Abstract}

Lead $(\mathrm{Pb})$ is an environmental pollutant and has detrimental effects on human health. Apigenin (APG) is a flavonoid that have antioxidant, anti-inflammatory, antiallergic, and cardioprotective effects and is presented as treatment of some diseases. The aim of the present study was to evaluate the probable protective effect of APG against Pb-induced toxicity in rats. Adult male rats were given either $\mathrm{Pb}$ (as lead acetate; 20 $\mathrm{mg} / \mathrm{kg}$ ) alone or in combination with APG $(20 \mathrm{mg} / \mathrm{kg})$ daily for 4 weeks by intraperitoneally injection (i.p). At the end of the experimental period, $\mathrm{Pb}$ accumulation, lipid profile, thyroid, and testicular function alterations were assessed. In addition, histopathological changes in the testis were assessed.Results revealed that $\mathrm{Pb}$ treatment significantly increased $\mathrm{Pb}$ concentrations in blood, thyroid gland, and in testis of rats. Further, the blood levels of hormones related to thyroid gland and testis were altered in $\mathrm{Pb}$-treated rats. In parallel, low sperm count and sperm motility, increased sperm abnormalities, and marked pathological changes in testis were observed. On the contrary, the treatment with both $\mathrm{Pb}$ and APG recorded amelioration of the deleterious effects of $\mathrm{Pb}$, involving attenuation of changes in lipid profile, thyroidal and testicular hormonal levels, sperm parameters and pathological changes in Pb treated rat's testis. In conclusion, it appears that dietary APG can ameliorate lead acetate induced hyperlipidemia, hypothyroidism and hypogonadism in male rats.

\section{Introduction}

Hyperlipidemiaoccured when serum cholesterol or triglycerides levels are elevated and reach levels linked with an increased risk of is chemic heart disease (Walker and Edwards, 2004). Several studies suggested that exposure to lead (Pb) may induce hypercholesterolemia, hypertriglyceridemia and hyperphosphatemia (Vgbaja et al., 2013).

Thyroid gland is an endocrine gland that regulates many body functions by secreting triiodothyronine (T3) and thyroxine (T4) and calcitonin hormones (Tortora and Derrickson, 2017). Previous studies have found that lead has the ability to induce hypothyroidism (Krieg, 2019).

Infertility is a health problem that affects about $15 \%$ of couples of reproductive ages (Lukac et al., 2009). Pb is a heavy metal with many industrial uses such as manufacturer of lead acid batteries, coloring agents, paints, smelters, and printing presses (Zhang et al., 2020). It causes environmental pollution and health problems (Okereafor et al., 2020). Pb is a major factor affecting male fertility (Al-Chalabi et al., 2014, El-Nekeety et al., 2009).

Attention has been given to phytotherapy researches to use medical plants with antioxidant activity for protection against heavy metal toxicity (El-Nekeety et al., 2009).

Apigenin (APG) is a natural plant belonging to flavonoids and is found mainly in many plants such as fruits, vegetables and herbs (chamomile celery, celeriac and parsley) (Kabera et al., 2014, Ghitu et al., 2019). It has been documented that Apigenin has antioxidant, antiinflammatory, anti-lepidemic and anti-apoptic effects (Lee et al., 2007, Shukla et al., 2014, Venigalla et al., 2015, Zhang et al., 2017).

Therefore, the present study was carried out to investigate the protective role of APG against the alteration in lipid profile and toxicity of Pb in testis and thyroid gland of treated rats. This was done using biochemical and structural assessments.

\section{Materials And Methods Chemicals}

Lead acetate was purchased from Sigma Chemicals (St. Louis, MO, USA). APG (Cat. No. 520-36-5) was purchased from (Matrix Scientific, Columbia, SC). Levels of total cholesterol (TC), triglycerides (TGs), and high-density lipoprotein cholesterol (HDL-C) were determined by standard kits (BIOMED Diagnostics, Germany). the units were expressed as $\mathrm{mg} / \mathrm{dL}$.Malondialdehyde level, as an indicator for lipid peroxidation, Superoxide dismutase, Catalase and glutathione peroxidase activities were determined using commercial kits (catalog \# MD2528, SD2520, CA2516, GP2524 respectively) obtained from Diagnostic, Giza, Egypt. TNF a was determined using Human ELISA Kit (catalog \# EA100365) OriGene Technologies Inc., Rockville, MD, IL-6 was determined using Rat Interleukin 6 (IL-6) ELISA Kit (catalog \# MBS726707), IL-4 was determined using Rat Interleukin 4 (IL-4) ELISA Kit (catalog \#MBS162452) , Interleukin 10 (IL-10) was determined using Interleukin 10 (IL-10) ELISA Kit ELISA Kit (catalog \#MBS764911) MyBioSource, Inc., San Diego, USA. Determination of caspase-3 was done using Biotechne kit (catalog \# BF3100) (USA). T4 ELISA kit (Cat. No. 60863) was purchased from Kamiya Biomedical Company, WA, USA. T3 solid-phase competitive ELISA kit (Cat. No. T3043T-100) was obtained from CalbioTech Inc., Spring Valley, Canada. TSH ELISA kit (Cat. No. CSBE05115r) was obtained from CUSABIO Biotech Co., LTD, Wuhan, China. Kit for determination of T was purchased from K-assay, WA, USA. LH and FSH kits were obtained from Biovender, Tokyo, Japan. Determination of caspase-3 was done using Biotechne kit (catalog \# BF3100) (USA). 


\section{Animals}

Twenty-four adult male rats (Rattus norvegicus) weighing 180-200gm were purchased from the animal house of Faculty of Science king Faisal University, Saudi Arabia. All experimental procedures were done according to the research ethics at King Faisal University. The rats were housed in plastic cages ( 6 per cage), floored with soft a wood shaving that was changed three times per week. The animals were acclimatized for 2 weeks prior the study and were maintained under a $12 \mathrm{~h} \mathrm{light/dark} \mathrm{cycle} \mathrm{at}\left(25^{\circ} \mathrm{C} \pm 2{ }^{\circ} \mathrm{C}\right)$, with free access to water and rat chow.

\section{Preparation of treatment materials:}

- Lead acetate dose: dosage of $20 \mathrm{mg} / \mathrm{kg}$ body weight (b.w.) was dissolved in normal saline and administrated intraperitoneally (i.p.) (ElNeweshy and El-Sayed, 2011).

- Apigenin dose: Apigenin (20mg/kg b.w.) was dissolved in normal saline and administrated (i.p.) (Venigalla et al., 2015, Yang et al., 2017).

\section{Experimental design:}

Animals were randomly divided into four groups of six animals each as follows:

Group I: served as the control group. Rats were daily injected (i.p.) with normal saline (0.9\% $\mathrm{Na}$ cl) as vehicle.

Group II: Served as lead acetate - treated group. Rats were daily injected (i.p) with lead acetate dissolved in normal saline at a dose of $20 \mathrm{mg} / \mathrm{kg}$ b.w.

Group III: Served as lead acetate and Apigenin-treated group. Rats were daily injected (i.p) with lead acetate dissolved in normal saline at a dose of $20 \mathrm{mg} / \mathrm{kg}$ (b.w.) followed by injection (i.p) with Apigenin dissolved in normal saline at dose of $20 \mathrm{mg} / \mathrm{kg}$ b.w.

Group IV: Served as Apigenin-treated group. Rats were daily injected (i.p) with Apigenin dissolved in normal saline at dose of $20 \mathrm{mg} / \mathrm{kg}$ b.w.

At the end of the 4-week experimental period, the animals were sacrificed and samples of blood and testis tissues were collected for analysis.

\section{Estimation of studied parameters:}

\section{a) Evaluation of lead level:}

The lead concertation was determined in blood and cerebellum tissue using Atomic Absorption Spectroscopy.

\section{b) Biochemical parameters:}

\section{I-Determination of serum lipid profile parameters}

Levels of total cholesterol (TC), triglycerides (TGs), and high-density lipoprotein cholesterol (HDL-C) were determined by standard kits according to the instructions of the supplier. The levels of LDL-cholesterol (LDL-C) was calculated using Friedewal's formula, the units were expressed as $\mathrm{mg} / \mathrm{dL}$.

\section{Preparation of tissue homogenate}

Chosen tissues were immediately removed and washed using chilled saline solution. These tissues were minced and separately homogenized $(10 \% \mathrm{w} / \mathrm{v})$ in ice-cold sodium-potassium phosphate buffer $(0.01 \mathrm{M}, \mathrm{pH} 7.4)$ containing $1.15 \% \mathrm{KCl}$ using a homogenizer (Potter-Elvehjem). The homogenate was centrifuged at $10,000 \mathrm{xg}$ for $20 \mathrm{~min}$ at $4^{\circ} \mathrm{C}$ and the resultant supernatant was used for the assay of the enzyme activities, the level of MDA and the protein. The protein content of the tissues was determined by the method of Lowry et al. (1951).

\section{II-Oxidative stress markers}


- Activities of catalase, superoxide dismutase, glutathione peroxidase were determined in chosen tissues using commercial kits. The enzymes activities were expressed as $\mathrm{U} / \mathrm{mg}$ protein. The level of MDA, as an index of lipid peroxidation, was determined through its reaction with thiobarbituric acid (TBA) using the lipid peroxidate kit according to the instruction of the supplier. TBARS values were calculated as nmol MDA per g tissue.

\section{III- Inflammatory markers}

The sera TNF- $\mu$, IL-6, IL-4 and IL-10 levels were measured using standard kits according to the manufacturer's protocol.

\section{IV- Apoptosis marker}

The levels of caspase-3 enzyme in cerebellum tissue were measured according to the manufacturer's protocol.

\section{V-Estimation of serum hormonal concentrations}

Thyroid hormones were determined by measuring the serum levels of thyroxine (T4), triiodothyronine (T3) and thyroid-stimulating hormone (TSH). T4 was determined following the protocol described in T4 ELISA kit (Cat. No. 60863), Kamiya Biomedical Company, WA, USA. The data of T4 were measured as $\mathrm{ng} / \mathrm{ml}$. T3 was estimated using a solid-phase competitive ELISA kit (Cat. No. T3043T-100) obtained from CalbioTech Inc., Spring Valley, Canada. The T3 values were expressed as pg/dl. TSH was estimated using ELISA kit (Cat. No. CSBE05115r) obtained from CUSABIO Biotech Co., LTD, Wuhan, China. The records of TSH were given in $\mu \mathrm{IU} / \mathrm{ml}$. Serum levels of testosterone, LH, and FSH were detected according to Sakuma (2009), Shioya and Wakabayashi (1998), and Teerds et al. (1989), respectively. The values of testosterone were expressed as $\mathrm{pg} / \mathrm{ml}$ whereas LH and FSH values were expressed as $\mathrm{ng} / \mathrm{ml}$.

\section{VI-Assessment of sperm concentration, motility, and abnormality}

The left testis of each rat was harvested, then minced in pre-warmed saline $\left(37^{\circ} \mathrm{C}\right)$, and the resulted suspension was used in semen analysis. To analyze sperm motility, 1 drop of sperm suspension was placed on a glass slide to analyze 200 motile sperm in 4 different fields. The motility of the sperm was evaluated microscopically within 2- 4 min of their isolation from the testis, and data were expressed as percentage motility (Morrissey et al. 1988). The sperms were counted using a hemocytometer following the method of Freud and Carol (1964). The technique of Evans and Maxwell (1987) was adopted for sperm abnormality study. Briefly, smears were made by placing a drop from the sperm suspension and one or two drops of the previously warmed $\left(37^{\circ} \mathrm{C}\right)$ eosin-nigrosin stain. The smears were allowed to dry in the air and then examined under the microscope using a high power (100x) oil immersion objective. The normal sperm cells were counted and the percentage was calculated.

\section{Microscopic examination}

For preparation of samples used in the examination by light microscope, specimens of testis were collected from all experimental groups and fixed in $10 \%$ neutral buffered formalin and routinely processed for stained with hematoxylin and eosin stain (H\& E) (Bancroft and Camble, 2002), then sections were examined using light microscope.

\section{D- Statistical analysis}

All variables were compared using one-way analysis of variance (ANOVA) followed by LSD multiple range test. Differences at $P<0.05$ were considered as statically significant.

\section{Results}

\section{Effect of Apigenin on lead levels in the testis and thyroid gland of rats treated with lead acetate}

In this study, there was a significant increase in lead level in the serum, thyroid gland and testis tissues of rats treated with lead acetate (GII) relative to control- group (GI). Treatment with APG caused decrease in lead level in serum and the tissues of rats intoxicated with lead acetate 


\section{Effect of Apigenin on lipid profile in sera of rats treated with lead actate}

Effect of APG on lipid profile in rats treated with lead acetate is shown in Table 2. It is obvious that exposure of rats to lead acetate produced significant increase in the values of TC, TGs and LDL-C, relative to the control group. Also, the results showed that HDL-C level was significantly decreased relative to that obtained for control group. On the contrary, APG treatment attenuated these changes in lipid profile.

\section{Effect of APG on oxidative stress markers in testis and thyroid gland tissues of rats treated with lead acetate}

In the present study, as shown in Table 3, rats treated with lead acetate (GII) showed significant decrease in studied antioxidant enzymes activities in thyroid gland and testis tissues as compared to the control group (GI). Also, there was a significant increase in the MDA levels in these tissues as compared to the control group (GI). These changes were markedly attenuated by the treatment with APG.

\section{Effect of APG on inflammation response in testis and thyroid gland tissues of rats treated with lead acetate}

Exposure of rats to lead acetate caused increase in levels of proinflammatory cytokines (IL-6 and TNF-a) and decrease in levels of antiinflammatory cytokines (IL-4 and IL-10) response in testis and thyroid gland tissues compared to the control group. On the other hand, rats treated with APG showed a significant decrease in the levels of pro-inflammatory cytokines and a significant increase in the levels of antiinflammatory cytokines in comparison to the lead acetate treated group (Table 4).

\section{Effect of Apeginin on caspase 3 in testis and thyroid gland tissues of rats treated with lead acetate}

In this study, there was a significant increase in caspace-3 activities (Table 5) in testis and thyroid gland tissues of rats treated with lead acetate (GII) relative to control- group (GI). These changes were markedly ameliorated by the treatment with APG.

\section{Effect of Apigenin on testicular and thyroid gland hormones in sera of rats treated with lead acetate}

In the present study, it was observed a decrease in T, LH and FSH in sera of rats treated with $\mathrm{Pb}$. Furthermore, there was a reduction in levels of T3 and T4 and an increase in TSH level. on the contrary, APG increased the levels of altered hormones in the sera of rats treated with Pb (Table 6).

\section{Effect of APG on sperm parameters in rats intoxicated with lead acetate}

The result of this study showed that Lead treatment induced a significant decrease in sperm count and sperm motility and increase in sperm abnormalities. However, the alterations in these sperm parameters were ameliorated in animals that received Pb plus APG when compared to rats treated with $\mathrm{Pb}$ alone (Table 7 ).

\section{Control group and Apigenin treated -group:}

In paraffin cross sections of Control \& Apigenin rat's testes fixed in formaldehyde and stained with H\&E, it was noticed well preserved seminiferous tubules separated by the interstitial tissue (Fig.1,7). Leydig cells occupied the interstitial tissue and each seminiferous tubule was lined with multiple layer of spermatogenic epithelium. The lumina of seminiferous tubules were occupied by the spermatozoa (Fig. 2,8).

\section{Lead acetate-treated group:}


In this group, light microscopically examination of H\&E testicular sections revealed extremely severe and widespread degenerative changes appeared as deformities of seminiferous tubules lined with wavy outline and surrounded by irregular basement membrane. Also, distinctive appearance of genotoxicity with degenerated interstitial tissue led to large spaces between the seminiferous tubules (Fig.3). Tubules exhibit focal or diffuse extensive necrosis with a few viable cells. The cells were identified in some tubules mostly composed of immature form of germ cells which appeared as small acidophilic cells have darkly stained nuclei. The irregular basement membranes of seminiferous tubules were lined with one or two layers of cells (Fig.4).

\section{Lead acetate and Apigenin treated group:}

In contrast, prior Apigenin treatment reduced the degree and the number of necrotic seminiferous tubules. There were relatively well preserved interestitium between seminiferous tubules. The interstitial spaces were narrow and most of the seminiferous tubules regained their normal appearance with more spermatozoa (Figs.6,7). Less improvement was recorded in few seminiferous tubules with depletion of germ cells but with healthy Leydig and spermatogenic cells (Fig.8).

Light micrographs of testis sections fixed in formaldehyde \&stained with H\&E. (1): control - section showing typical architecture with oval seminiferous tubules (ST) separated by narrow interstitial tissue (arrows) (2) Enlarged part from figure (1) (dashed-circle) showing smooth seminiferous tubules with aggregation of matured spermatozoa in the lumen(S) \& sequence of spermatogenic cells. Note, Leydig cells(arrows)(3) lead acetate-section showing distorted arrangement of seminiferous tubules (ST) with wide lytic interstitial tissue (star) .(4) Wavy outline seminiferous tubules showed degeneration of spermatogenic cells with deeply stained nuclei(circle) and deformed spermatozoa (S) .(5) Seminiferous tubules of Lead+ Apigenin - group showing variable degree of healthy units (ST) and restoration of spermatogenesis are evident .Note, well preserved interstitial tissue (arrows) .(6) Enlarged part from figure(5)(dashed-circle) showing oval unite with histopathological pattern of damage in few of seminiferous tubules . Note, healthy Leydig cells (arrows) (7) Seminiferous tubules of Apigenin - group showing nearly normal structure (ST) with an organized distribution of various spermatogenic stages and interstitial tissue. (8) Seminiferous tubules showing germinal epithelium (circle) more or less normal with aggregation of spermatozoa in the lumen (S).

\section{Discussion}

\section{Effect of Apigenin on lead levels in the testis and thyroid gland}

The present study showed that $\mathrm{Pb}$ can be bioaccumulated in the testis and thyroid gland of treated rats as indicated by increased level of $\mathrm{Pb}$ in these tissues. Similar results were previously reported by Basalamah et al. (2018). On the other hand, APG treatment can decreases levels of $\mathrm{Pb}$ in testis and thyroid gland. This may be due to the ability of APG to chelate Pb (Riceevans et al., 2017).

\section{Effect of Apigenin on lipid profile in rat treated with lead actate}

With respect to the serum lipid profile, results detained from the present study indicated that lead exposure was associated with increase in the level of total cholesterol, triglycerides and LDL cholesterol and decrease in HDL cholesterol. These results concurred with the findings of (Ige et al., 2019).

It is well known that low level of HDL and high levels of TC, TG an LDL increase the risk of atherosclerosis and cardiovascular diseases (Adeniyi and Soladoye, 2017). Increased level of lipid profile may be due to increased uptake of exogenous cholesterol and subsequent deposition and decreased cholesterol catabolism. The ability of $\mathrm{Pb}$ to develop hypercholesterolemia may involve the activation of cholesterol biosynthetic enzymes and simultaneous suppression of cholesterol catabolic enzymes (Ademuyiwa et al., 2005).

On the other hand, APG treatment minimized these changes in lipid profile induced by Pb. This finding is in agreement with that of (El-Barky et al., 2019) in diabetic rats and (Khudiar et al., 2017) in cadmium chloride treated rats. This may be due to the ability of APG to reduce the level of blood fat by promoting cholesterol absorption and conversion, and accelerating reverse cholesterol transport (Zhang et al., 2016).

\section{Effect of APG on oxidative stress markers in testis and thyroid gland of rats treated with lead acetate}

The data of the present study showed that $\mathrm{Pb}$ can induced oxidative stress in tissues of testes and thyroid gland of treated rats as shown by the observed decrease in the activities of studied antioxidant enzymes and increase in level of MDA in these tissues. This result is in agreement with that reported by Ezejiofor and Orisakwe, (2019) .On the contrary, APG reduced this observed oxidative stress in testis and 
thyroid gland. These results agree with the results of Dang et al. (2017) in case of testis of acrylamide treated rats and Panda and Kar (2007) in the thyroid gland of diabetic mice.

The ability of APG treatment to reduce the oxidative stress induced by $\mathrm{Pb}$ in testis and thyroid glands may be due to the antioxidant activity of APG which is mainly determined by three hydroxyl groups at its 4', 5, 7 position and double bond at C2 and C3 (Pan et al., 2020 ).

\section{Effect of APG on inflammation response in testis and thyroid gland of rats treated with lead acetate}

The result of the present study showed that $\mathrm{Pb}$ treatment caused increase in proinflammatory cytokines levels (TNF- $\alpha$ and I L-6) and decrease in anti-inflammatory cytokines levels (IL-4 and IL-10) in both testis and thyroid gland. These results can be supported by previous finding of Basalamah et al. (2018).

\section{Effect of Apeginin on caspase 3 in testis and thyroid gland of rats treated with lend acetate}

Caspases are a family of genes that play a role in maintaining homeostasis by regulating cell death and inflammation (Mcllvain et al., 2013).

Our findings clearly showed that the activity of caspase-3 was increases in tests and thyroid gland of rats treated with lead acetate which may indicate that $\mathrm{Pb}$ had the ability to induce apoptosis in these tissues. These results are in agreement with Massanyi et al. (2020) studies on $\mathrm{Pb}$ apoptic effect in the spermatogenetic cells

The co-administration of Pb and APG decrease the observed apoptic effect of Pb. In parallel with this result, Skondras et al. (2015) demonstrated the ability of APG to attenuate the apoptic effect induced in rat's testis in experimental ischemia-reperfusion. Also, Abdel Kareem and Mahmoud (2017) demonstrated this effect in thyroid of rats intoxicate with deltamethrin.

\section{Effect of Apigenin on testicular and thyroid gland hormones in rats treated with lead acetate}

In the present study, a decrease in T, LH and FSH in sera of rats treated with $\mathrm{Pb}$ was observed. These findings were supported by the results obtained by Kelainy et al. (2019). Furthermore, there was a a reduction in levels of T3 and T4 and an increase in TSH level. Similar results were obtained by Al-Maathidy et al. (2019).

The decrease in T level by $\mathrm{Pb}$ may be due to its ability to produce reactive oxygen species which promote Leydig cells aging and apoptosis. It is well known that Leydig cells are responsible for T secretion (Adekola (2015). The observed alterations in testicular and thyroid gland hormones indicated impairment in function of testis and hypothyroidism.

The observed hypogonadism may be a consequence of hypothyroidism where it is well known that hypothyroidism is associated with a decrease in male sex hormones, abnormal spermatogenesis, and retardation of Sertoli cell differentiation (Mohamed and Gawad, 2017). T3 hormone has the ability to stimulate the basal testosterone biosynthesis by increasing LH receptors and steroidogenesis of Leydig cells (Maran et al. 2000). T3 also regulates mitochondrial function in several tissues (Chattopadhyay et al. 2010).

The observed thyroid dysfunction may be related to structural damage of thyroid follicular cells due to accumulation of Pb in the thyroid gland (Baoliei et al., 2009). The observed increase in serum TSH level is likely a response to decreases serum T4 and T3 level.

On the contrary, APG increased the levels of altered hormones in the sera of rats treated with Pb. This effect can be supported by the finding of Akilah et al. (2018) in testes of rats treated with chloroquinone and Panda and Karin in thyroid gland of diabetic mice.

\section{Effect of APG on sperm parameters in rats intoxicated with lead acetate}

In the present study, exposure of rats to $\mathrm{Pb}$ showed altered sperm parameter where there were a decrease in sperm count and motility and an increase in sperm abnormality. This result can be supported by that of Oyeyemi et al. (2019).

It is well known that sperm plasma membranes are rich in polyunsaturated fatty acids, containing double bonds vulnerable to free radical attack and initiation of lipid peroxidation which causes impaired membrane structure and functions (Tvrda et al., 2011, Asadpour et al., 2013).

Page $7 / 15$ 
The observed decrease in sperm count may be due to the ability of $\mathrm{Pb}$ to cause oxidative stress and consequently increased death and decreased number of sperms (Tvrda et al., 2011).

$\mathrm{Pb}$ may interact with sulfhydral groups on the proteins of the outer dense fibers and fibrous sheath, which are cytoskeletal components of the flagellum, causing its detachment from the plasma membranes and this may affect the sperm motility (Gomes et al., 2015).

On the other hand, APG treatment ameliorated the alteration in sperm parameters. This may be due to the ability of APG to reduce oxidative stress as demonstrated in this study. Similar result was obtained by (Akilah et al.,2018) in testes of rats treated with chloroquinone.

\section{Effect of Apigenin on testis histology.}

In the present study, lead acetate led to degenerative changes in the testis of treated rats. This result can be confirmed by those of Soliman et al. (2017) and Ali et al. (2018).

\section{Conclusion}

In summary, it can be concluded that $20 \mathrm{mg} / \mathrm{kg}$ b.w of lead acetate for 4 weeks can induce toxicity in testis and thyroid gland of rats. On the contrary, treatment with APG had (20mg/kg b.w) can attenuate change in lipid profile and had beneficial effect for prophylaxis of Pb-induced testicular and thyroid gland damages.

Results of the current study shows that APG treatment may exhibit these prophylactic effects through anti-hyperlipidemic, antioxidant, antiinflammatory and anti-apoptic activities of APG.

\section{Declarations}

\section{Ethical approval}

The experimental protocol of this investigation was approved by Institutional Animal Care and Use Committee (IACUC) at the King Faisal University.

\section{Funding}

No funding agency support this research.

\section{Declaration of Competing Interest}

The authors report no declarations of interest.

\section{Data and materials Availability}

We have no conflict to publish our data

\section{Author Contributions}

- Abdulmohsen I. Algefare conceived and designed the experiments, performed the experiments, analyzed the data, contributed reagents/materials/analysis tools, prepared figures and/or tables, authored or reviewed drafts of the paper, approved the final draft.

-Azza Sedky conceived and designed the experiments, performed the experiments, analyzed the data, prepared figures and/or tables, authored or reviewed drafts of the paper, approved the final draft.

- Manal Alfwuaires analyzed the data, contributed reagents/materials/analysis tools, authored or reviewed drafts of the paper, approved the final draft.

- Omar Mahmoud analyzed the data, prepared figures and/or tables, authored or reviewed drafts of the paper, approved the final draft. 


\section{Consent to Participate}

Consent to Participate I/we certify that I/we have participated sufficiently in the intellectual content, conception and design of this work or the analysis and interpretation of the data (when applicable), as well as the writing of the manuscript, to take public responsibility for it and have agreed to have my/our name listed as a contributor. I/we believe the manuscript represents valid work. Neither this manuscript nor one with substantially similar content under my/our authorship has been published or is being considered for publication elsewhere, except as described in the covering letter. I/we certify that all the data collected during the study is presented in this manuscript and no data from the study has been or will be published separately. I/we attest that, if requested by the editors, I/we will provide the data/information or will cooperate fully in obtaining and providing the data/information on which the manuscript is based, for examination by the editors or their assignees. Financial interests, direct or indirect, that exist or may be perceived to exist for individual contributors in connection with the content of this paper have been disclosed in the cover letter. Sources of outside support of the project are named in the cover letter. I/We hereby transfer(s), assign(s), or otherwise convey(s) all copyright ownership, including any and all rights incidental thereto, exclusively to the Journal, in the event that such work is published by the Journal. The Journal shall own the work, including 1) copyright; 2) the right to grant permission to republish the article in whole or in part, with or without fee; 3 ) the right to produce preprints or reprints and translate into languages other than English for sale or free distribution; and 4) the right to republish the work in a collection of articles in any other mechanical or electronic format. We give the rights to the corresponding author to make necessary changes as per the request of the journal, do the rest of the correspondence on our behalf and he/she will act as the guarantor for the manuscript on our behalf. All persons who have made substantial contributions to the work reported in the manuscript, but who are not contributors, are named in the Acknowledgment and have given me/us their written permission to be named. If I/we do not include an Acknowledgment that means I/we have not received substantial contributions from non-contributors and no contributor has been omitted

\begin{tabular}{|l|c|}
\hline Participant & Signature \\
\hline - Abdulmohsen I. Algefare & \\
\hline -Azza Sedky & \\
\hline - Manal Alfwuaires & omar Mahmoud \\
\hline - Omar Mahmoud & \\
\hline
\end{tabular}

\section{Consent to Publish}

The authors report no conflict to publish

\section{References}

1. Ali A, Al-Derawi H, Al Mansour A (2018) Testicular toxic effect of lead acetate on adult male rats and the potential protective role of alcoholic extract of ginseng (histological, histomorphometrical and physiological. Sci J Med Res 2(6):87-92

2. Abdelkareem Z, Mahmoud A (2017) Antipoptic effect of apigenin and vitamin E against deltamthrin induced toxicity in rats. Zagazig J Pharma Sci 26(2):67-77

3. Adekola L (2015) Effects of colutathione depletion on leydig cell Aging and steroidogenesrs. Johns Hopkins University, Maryland, pp 141

4. Ademuyiwa O, Vgbaja R, Idumebor F, Adebawa O (2005) Plasma lipid profiles and risk of cardiovascular disease in occupational lead exposure in Abeokuta, Nigeria. Lipids Health Dis 4:19

5. Adeniy MJ, Soladoye AO (2017) Plasma lipid profile and uric acid in high fat fed female rats treated with oral contraceptive. Biomed J Sci Tech Res 1(2):526-535

6. Akilah A, Balaha M, Abd-El Rahman M, Hedya S (2018) Apigenin and baicalin, each alone or in low-dose combination, attenuated chloroguine induced male in fertility in adult rats. Thai J Pharma Ceuti Sci; 42(3):118-128

7. Al-Chalabi S, Abdul-Lattif R, Sabrci D (2014) Physiological and histological effect of aqueous and alcoholic extract of Garlic (Allim sativum) on testicular function of albino male mice treated with lead acetate. J Biotechnol Res Cent 8(2):41-48

8. Al-Maathidy A, Alzyoud JA, Al-Dalaen S, Al-Qtaitat A (2019) Histological alterations in the thyroid follicular cells induced by lead acetate toxicity in adult male albino rats. Int J Pharmaceut Phytopharmacol Res 9(5):19-26

9. Asadpour R, Shahbazfar A, Kianifard D, Azari M, Zaboli N (2013) Comparison of the protective effects of garlic (Allium Sativum L) extract, vitamin $\mathrm{E}$ and Nacetyl cysteine on testis structure and sperm quality in rats treated with lead acetate. Revue Med Vet 164:27-33

Page 9/15 
10. Bancroft D, Gamble M (2002) The theory and practice of histological technique, 5th edn. Churchill Livingstone; London, $\mathrm{p} 75$

11. Baoliei K, Nikghadam P, Mostaghni K, Zarifi M (2009) Effect fo lead on thyroid function in sheep. Iranian J Veterin Res Shiraz Univ 10(3):28

12. Basalamah M, Abdelghany A, El-Boshy M, Ahmad J, Idris S, Refaat B (2018) Vitamin D alleviates lead induced renal and testicular injuries by immunomodulatory and antioxidant mechanisms in rats. Sci Rep 8:4853

13. Dang Y, Li Z, Luo B, Pan L, Wei Q, Zhang Y (2017) Protective effects of apigenin against acrylamide-induced sub-chronic sperm injury in rats. Food Chem Toxicol 109(Pt 1):517-525

14. El Barky AR, Ezz AA, El-Said KS, Sadek ME, Mohamed TM (2019) Anti-Diabetic Activity of Egyptian Celery APigenin. Asian J Dairy Food Res 38(4):341-346

15. El-Nekeety A, El-Kady A, Soliman M, Hassan N, Abdel-Wahhab A (2009) Protective effect of Aquilegia Vulguris (L) against lead acetateinduced oxidative stress in rats. Food Chem Toxicol 47:2209-2215

16. El-Neweshy M, El-Sayed S (2011) Influence of vitamin C Supplementation on on lead-induced histopathological alterations in male rats. Exp Toxicol Pathol 63(3):221-227

17. Evans G, Maxwell WMC (1987) Handling and examination semen. In: Maxwell WMC (ed) Salamon's artificial insemination of sheep and goat. Butterworths, Sydney 1987: pp 93-106

18. Ezeijofor A, Orisakwe O (2019) The protective effect of costus after ker Gawl aqueous leaf extract on lead-induced reproductive changes in male albino wistar rats. JBRA Assist Reford 23:215-224

19. Freud M, Carol B (1964) Factors affecting haemocytometer count of sperm concentration in human semen. J Report Fertil 8:149-155

20. Friedewald W, Levy R, Fredrickson D (1972) Clin Chem 18(6):499

21. Friedewald WT, Levy RI, Fredrickson DS (1972) Estimation of the concentration of low-density lipoprotein cholesterol in plasma, without use of the preparative ultracentrifuge. Clin Chem 18(6):499-502

22. Ghitu A, Schwiebs A, Radeke H, Avroum S, Zupko I, Bor A et al (2019) Acomprehensive Assessment of Apigenin as an antiproliferative, proapoptic, antiangiogonic and immunomodulatory phytocompound, 11. Nutrients, p 858

23. Ige SF, Adeniyi MJ, Joanna AO, Oluwaseyi DA (2019) Allium Cepa juice prevented oxidative stress-mediated metabolic disorder following chronic lead acetate exposure in male rats. AJMHS; 50(1):p 11

24. Kaberou J, Seman E, Mussa A, He X (2014) Plant secondary metabolites: Biosynthesis, classification, function and pharmacological properties. J Pharm Pharmacol 2:377-392

25. Kelain E, Laila I, Ibrahim S (2019) The effect of ferulic acid against lead-induced oxidative stress and DNA drainage in kidney and testes of rats. Environ Sci Pollut Res Int 26:31675-31684

26. Khudiar KK, Al-Mezain AK, Al Mezain KA (2017) Hypolipidemic effect of Agigenin extract form parsley (Petroselinum Sativum L.) Leaves in cadmium chloride treated rats (Part II). J Kerbala Agricult Sci 4(5):125-139

27. Krieg J (2019) The relationships between blood lead levels and serum thyroid stimulating hormone and total thyroixne in the third National Health and Nutrition Examination Survey. J Trace Elements Med Biol 1(51):130-137

28. Lee JH, Zhou HY, Cho SY, Kim YS, Lee YS, Jeong CS (2007) Anti-inflammotory mechanisms of apigenin: inhibition of cyclooxygenasezexpression, adhesion of monocytes to human umbilical vein endothelial cells, and expression of cellular adhesion molecules. Arch Pharmacol Res 30(10):1318-1327

29. Lukac N, Massanyi P, Krockova J, Nad P, Slamecka J, Ondruska L et al (2009) Relationship between trace element concentrations and spermatozoa quality in rabbit semen. Slovak J Anim Sci 42:46-50

30. Massanyi P, Lukac N, Massanyi M, Stawarz R, Formicki G, Danko J (2020) Effects of xenobioties on animal reproduction in vivo: Microscopical examination, 26. Microse Microanal, p 63

31. Mcllvain D, Berger T, Mark T (2013) Caspase function in cell death and diseas. Cold spring Harb Perspect Boil 5:a008656

32. Morrissey RE, Schwetz BA, Lamb JC et al (1988) Evaluation of rodent sperm, vaginal cytology, and reproductive organ weight data from national toxicology program 13-week studies. Toxicol Sci 11(2):343-358. https://doi.org/10.1093/toxsci/11.1.343

33. Okereafor V, Makhatha M, Mekuto L, Vche-Okereafor N, Sebola T, Mavumengwana V (2020) Toxic metal implications on Agricultural Soils, plants, animals, aquatic life and human health. Int J Environ Res Public Health 17:2204

34. Oyeyemi W, Princely A, Oluwademilare A, Oore-oluwapo D, Blessing A, Alfred E (2019) Clomiphene citrate ameliorated lead-induced reproductive toxicity in male wistar rats. JBRA Assist Reprod 23:336-343

35. Pan X, Shao Y, Wand F, Cai Z, Liu S, Xi J et al (2020) Protective effect of apigeinin magnesium complex on $\mathrm{H}_{2} \mathrm{O}_{2}$-induced oxidative stress and inflammatory responses in rat hepatic stellate cells. Pharm Biol 58(1):553-560 
36. Panda S, Kar A (2007) Apeginin (4, 5, 7- trihydroxyflavone) regulates hyperglyceamia, thyroid dysfunction and lipid peroxidation in alloxan-induced diabetic mice. J Pharm Pharmacol 59(11):1543-1548

37. Shukla S, Gupta S (2004) Suppression of constitutive and tumor necrotic factor- $\delta$ induced nuclear factor NF-KB activation and induction of apoptosis by apigenin in human prostate carcinoma PC-3 cells: correlation with down-regulation of NF-KB responsive genes. Clin Cancer Res 10(9):3169-3178

38. Skondras I, Lambropoulu M, Tsaroucha A, Gardikis S, Tripsianis G, Simopoulos C et al (2015) The role of Apeginin in testicular damage in experimental-reperfusion injury in rats. Hippokrato 2015; 19 (3):225 - 30

39. Soliman A, Ganaie A, AlthurwiN, AlbaqamiF, Salkini A, Abdel-Kader S (2017) Extract of Salvadora persica roots attenuates lead acetateinduced testicular oxidative stress in rats. J Pharm Pharmacogn Res 5(4):239-250

40. Tortora GJ, Derrickson BH (2017) Introduction to the human body. John Wiley and Sons, Incorporate

41. Tvrda E, Knazicka Z, Bardos L, Massanyi P, Lukac N (2011) Impact of oxidative stress on male fertility-a review. Acta vet Hung 59:465484

42. Uabaja RN, Onunkwor BO, Omoniyi DA (2013) Lead induced dyslipidemia: The comparative effect of ascorbate and chelation therapy. Afr J Biotech 12(16):1845-1852

43. Venigalla M, Gyengesi E, Munch G (2015) Cur cumin and Apigenin-nouvel and promissing theraneurics. against chamic neuroinflammation in Al zheimer's disease. Neural Regener Res 10(8):1181-1185

44. Walker R, Edwards C (2004) Clinical pharmacy and therapeutics, 2nd edn. Churchil Livingstone, Landon, pp $321-322$

45. Yang X, Wang Q, Pang ZR, Pan MR, Zhang W (2017) Flavonoid - entiched from hippophae thamnoides seed teduces high fat diet indiced obesity, hypertrigly ceridemca and hepatic triglyceride accumulation in C57 BL/6 mice. Pharm Biol 55(1):1207-1214

46. Zhang K, Song W, Li D, Jin X (2016) A pigenin in the tegulation of cholesterol metabolism and protection of blood vessels. Experimental therapeutic Medicine 13(5):1719-1724

47. Zhang K, Song W, Li D (2017) Apigenin in the regulation of cholesterol metabolism and protection of blood vessels. Exp Ther Med 13(5):1719-1724

48. Zhang Y, Wang B, Cheng Q, Li X, Li Z (2020) Removal of toxic heavy metal inos ( $\mathrm{Pb}, \mathrm{Cr}, \mathrm{Cu}, \mathrm{Ni}, \mathrm{Zn}, \mathrm{Co}, \mathrm{Hg}$ and Cd) from waste batteries or lithium cells using Nano sized metal oxides: A Review. J Nanosci Nanotechmol 20(12):7231-7254

\section{Tables}

Table (1) The effect of apigenin on the lead level in sera, testis and thyroid gland of rats intoxicated with lead acetate

\begin{tabular}{lllll} 
& & Serum $(\mu \mathrm{g} / \mathrm{ml})$ & Testis $(\mu \mathrm{g} / \mathrm{g}$ tissue $)$ & Thyroid gland $(\mu \mathrm{g} / \mathrm{g}$ tissue $)$ \\
\hline Group I & 6 & $0.14^{\mathrm{c}} \pm 0.01$ & $0.13^{\mathrm{c}} \pm 0.01$ & $0.16^{\mathrm{c}} \pm 0.01$ \\
\hline Group II & 6 & $5.4^{\mathrm{a}} \pm 0.08$ & $3.4^{\mathrm{a}} \pm 0.07$ & $4.3^{\mathrm{a}} \pm 0.08$ \\
\hline Group III & 6 & $1.5^{\mathrm{b}} \pm 0.06$ & $0.96^{\mathrm{b}} \pm 0.03$ & $1.2^{\mathrm{b}} \pm 0.05$ \\
\hline Group IV & 6 & $0.12^{\mathrm{c}} \pm 0.01$ & $0.13^{\mathrm{c}} \pm 0.01$ & $0.14^{\mathrm{c}} \pm 0.01$ \\
\hline $\mathrm{F}(\mathrm{p})$ & & $2410.410^{\star}\left(<0.001^{*}\right)$ & $1787.467^{\star}\left(<0.001^{\star}\right)$ & $1676.828^{\star}\left(<0.001^{*}\right)$ \\
\hline
\end{tabular}

Normally distributed data was expressed in Mean \pm SE.

F: F for ANOVA test, Pairwise comparison bet. each 2 groups was done using Post Hoc Test (Tukey)

p: $p$ value for comparing between the studied groups

Means with Common letters are not significant (Means with Different letters are significant)

*: Statistically significant at $p \leq 0.05$

Table (2): Effect of Apigenin on lipid profile in sera of rats treated with lead acetate 
No.

TC

$(\mathrm{mg} / \mathrm{dL})$

TGs

HDL-C

LDL-C

$(\mathrm{mg} / \mathrm{dL})$

$(\mathrm{mg} / \mathrm{dL})$

$(\mathrm{mg} / \mathrm{dL})$

\begin{tabular}{llllll}
\hline Group I & 6 & $54.3^{\mathrm{c}} \pm 0.2$ & $36.3^{\mathrm{b}} \pm 0.2$ & $29.2^{\mathrm{a}} \pm 0.2$ & $17.1^{\mathrm{c}} \pm 0.2$ \\
\hline Group II & 6 & $114.5^{\mathrm{a}} \pm 0.2$ & $76.2^{\mathrm{a}} \pm 0.2$ & $17.4^{\mathrm{c}} \pm 0.1$ & $56.3^{\mathrm{a}} \pm 0.1$ \\
\hline Group III & $\mathbf{6}$ & $66.1^{\mathrm{b}} \pm 0.3$ & $48.8^{\mathrm{c}} \pm 0.1$ & $20.1^{\mathrm{b}} \pm 0.1$ & $29.5^{\mathrm{b}} \pm 0.1$ \\
\hline Group IV & 6 & $54.9^{\mathrm{c}} \pm 0.1$ & $36.5^{\mathrm{b}} \pm 0.2$ & $28.9^{\mathrm{a}} \pm 0.1$ & $17.6^{\mathrm{c}} \pm 0.2$ \\
\hline F (p) & & $\begin{array}{l}18921.525^{*} \\
\left(<0.001^{*}\right)\end{array}$ & $\begin{array}{l}10981.932^{*} \\
\left(<0.001^{\star}\right)\end{array}$ & $\begin{array}{l}2185.817^{*} \\
\left(<0.001^{*}\right)\end{array}$ & $\begin{array}{l}17914.596^{*} \\
\left(<0.001^{*}\right)\end{array}$
\end{tabular}

Normally distributed data was expressed in Mean \pm SE.

F: F for ANOVA test, Pairwise comparison bet. each 2 groups was done using Post Hoc Test (Tukey)

$p: p$ value for comparing between the studied groups

Means with Common letters are not significant (Means with Different letters are significant)

*: Statistically significant at $p \leq 0.05$

Table (3): Effect of Apigenin on oxidative stress markers induced in testis and thyroid grand tissues of rats treated with lead acetate

\begin{tabular}{|c|c|c|c|c|c|c|c|c|c|}
\hline & \multirow[t]{3}{*}{ No. } & \multicolumn{4}{|l|}{ Testis } & \multicolumn{4}{|c|}{ Thyroid grand } \\
\hline & & CAT & SOD & GPX & MDA & CAT & SOD & GPX & MDA \\
\hline & & $\begin{array}{l}\text { (U/mg } \\
\text { protein) }\end{array}$ & $\begin{array}{l}\text { (U/mg } \\
\text { protein) }\end{array}$ & $\begin{array}{l}\text { (U/mg } \\
\text { protein }\end{array}$ & $\begin{array}{l}\text { (nmol/g } \\
\text { tissue) }\end{array}$ & $\begin{array}{l}\text { (U/mg } \\
\text { protein) }\end{array}$ & $\begin{array}{l}\text { (U/mg } \\
\text { protein) }\end{array}$ & $\begin{array}{l}\text { (U/mg } \\
\text { protein }\end{array}$ & $\begin{array}{l}\text { (nmol/g } \\
\text { tissue) }\end{array}$ \\
\hline $\begin{array}{l}\text { Group } \\
\text { I }\end{array}$ & 6 & $45.0^{\mathrm{a}} \pm 0.45$ & $\begin{array}{l}65.74^{a} \\
\pm 0.26\end{array}$ & $\begin{array}{l}64.70^{\mathrm{a}} \\
\pm 0.30\end{array}$ & $12.72^{\mathrm{c}} \pm 0.4$ & $\begin{array}{l}44.40^{\mathrm{a}} \\
\pm 0.10\end{array}$ & $\begin{array}{l}45.22^{\mathrm{a}} \\
\pm 0.09\end{array}$ & $\begin{array}{l}65.52^{\mathrm{a}} \\
\pm 0.29\end{array}$ & $14.60^{C} \pm 0.5$ \\
\hline Group & 6 & $21.0^{c} \pm 0.45$ & $\begin{array}{l}27.20^{c} \\
\pm 0.37\end{array}$ & $\begin{array}{l}24.80^{\mathrm{c}} \\
\pm 0.24\end{array}$ & $\begin{array}{l}33.70^{a} \\
\pm 0.30\end{array}$ & $\begin{array}{l}15.52^{\mathrm{b}} \\
\pm 0.14\end{array}$ & $\begin{array}{l}27.28^{\mathrm{c}} \\
\pm 0.14\end{array}$ & $\begin{array}{l}20.24^{c} \\
\pm 0.10\end{array}$ & $35.38^{a} \pm 0.12$ \\
\hline $\begin{array}{l}\text { Group } \\
\text { III }\end{array}$ & 6 & $36.02^{b} \pm 0.27$ & $46.20^{\mathrm{b}} \pm 0.37$ & $\begin{array}{l}54.86^{b} \\
\pm 0.21\end{array}$ & $22.58^{\mathrm{b}} \pm 0.4$ & $\begin{array}{l}31.60^{c} \\
\pm 0.13\end{array}$ & $\begin{array}{l}37.60^{b} \\
\pm 0.51\end{array}$ & $\begin{array}{l}46.18^{b} \\
\pm 0.10\end{array}$ & $24.38^{b} \pm 0.8$ \\
\hline $\begin{array}{l}\text { Group } \\
\text { IV }\end{array}$ & 6 & $44.80^{\mathrm{a}} \pm 0.37$ & $66.0^{\mathrm{a}} \pm 0.32$ & $\begin{array}{l}63.60^{\mathrm{a}} \\
\pm 0.29\end{array}$ & $12.02^{\mathrm{C}} \pm 0.19$ & $\begin{array}{l}42.24^{a} \\
\pm 0.10\end{array}$ & $\begin{array}{l}44.46^{a} \\
\pm 0.16\end{array}$ & $\begin{array}{l}63.38^{a} \\
\pm 0.16\end{array}$ & $14.40^{\mathrm{C}} \pm 0.12$ \\
\hline$F(p)$ & & $\begin{array}{l}969.096^{*} \\
\left(<0.001^{\star}\right)\end{array}$ & $\begin{array}{l}3272.599^{*} \\
\left(<0.001^{*}\right)\end{array}$ & $\begin{array}{l}5754.810^{*} \\
\left(<0.001^{*}\right)\end{array}$ & $\begin{array}{l}5714.827^{*} \\
\left(<0.001^{\star}\right)\end{array}$ & $\begin{array}{l}12622.152^{*} \\
\left(<0.001^{*}\right)\end{array}$ & $\begin{array}{l}7397.031^{*} \\
\left(<0.001^{*}\right)\end{array}$ & $\begin{array}{l}14572.984^{*} \\
\left(<0.001^{*}\right)\end{array}$ & $\begin{array}{l}23360.667^{*} \\
\left(<0.001^{*}\right)\end{array}$ \\
\hline
\end{tabular}

Normally distributed data was expressed in Mean \pm SE.

F: F for ANOVA test, Pairwise comparison bet. each 2 groups were done using Post Hoc Test (Tukey)

$\mathrm{p}$ : $\mathrm{p}$ value for comparing between the studied groups

Means with Common letters are not significant (Means with Different letters are significant)

*: Statistically significant at $p \leq 0.05$

Table (4): Effect of Apigenin on inflammatory response in testis and thyroid gland tissues of rats treated with lead acetate 
No. Testis

Pro-Inflammatory
Thyroid grand

Pro-Inflammatory

Anti-Inflammatory

\begin{tabular}{|c|c|c|c|c|c|c|c|c|c|}
\hline & & IL-6 & TNF-á & IL-4 & IL-10 & IL-6 & TNF-á & IL-4 & IL-10 \\
\hline Group & 6 & $51.3^{c} \pm 0.14$ & $45.30^{c} \pm 0.14$ & $\begin{array}{l}49.30^{a} \\
\pm 0.14\end{array}$ & $\begin{array}{l}39.32^{a} \\
\pm 0.13\end{array}$ & $\begin{array}{l}44.20^{b} \\
\pm 0.09\end{array}$ & $45.40^{c} \pm 0.19$ & $\begin{array}{l}53.02^{a} \\
\pm 0.24\end{array}$ & $\begin{array}{l}34.50^{a} \\
\pm 0.22\end{array}$ \\
\hline Group & 6 & $\begin{array}{l}241.2^{a} \\
\pm 0.46\end{array}$ & $\begin{array}{l}226.8^{a} \\
\pm 0.25\end{array}$ & $\begin{array}{l}22.36^{c} \\
\pm 0.12\end{array}$ & $19.32^{c} \pm 0.14$ & $\begin{array}{l}202.7^{a} \\
\pm 0.59\end{array}$ & $\begin{array}{l}227.6^{a} \\
\pm 0.19\end{array}$ & $26.0^{c} \pm 0.35$ & $\begin{array}{l}17.60^{c} \\
\pm 0.29\end{array}$ \\
\hline $\begin{array}{l}\text { Group } \\
\text { III }\end{array}$ & 6 & $\begin{array}{l}101.14^{b} \\
\pm 0.3\end{array}$ & $\begin{array}{l}144.20^{b} \\
\pm 0.3\end{array}$ & $\begin{array}{l}36.74^{b} \\
\pm 0.25\end{array}$ & $\begin{array}{l}28.40^{b} \\
\pm 0.19\end{array}$ & $104.6^{c} \pm 0.29$ & $\begin{array}{l}145.6^{b} \\
\pm 0.19\end{array}$ & $33.30^{b} \pm 0.37$ & $24.64^{b} \pm 0.19$ \\
\hline $\begin{array}{l}\text { Group } \\
\text { IV }\end{array}$ & 6 & $53.2^{c} \pm 0.34$ & $44.6^{c} \pm 0.50$ & $\begin{array}{l}47.0^{\mathrm{a}} \pm \\
0.18^{-}\end{array}$ & $\begin{array}{l}37.60^{a} \\
\pm 0.29\end{array}$ & $43.7^{b} \pm 0.14$ & $47.6^{c} \pm 0.20$ & $\begin{array}{l}55.60^{a} \\
\pm 0.58\end{array}$ & $\begin{array}{l}35.34^{a} \\
\pm 0.15\end{array}$ \\
\hline$F(p)$ & & $\begin{array}{l}300063.477^{\star} \\
\left(<0.001^{\star}\right)\end{array}$ & $\begin{array}{l}151836.120^{*} \\
\left(<0.001^{*}\right)\end{array}$ & $\begin{array}{l}5630.931^{*} \\
\left(<0.001^{*}\right)\end{array}$ & $\begin{array}{l}2202.133^{\star} \\
\left(<0.001^{\star}\right)\end{array}$ & $\begin{array}{l}405960.114^{\star} \\
\left(<0.001^{\star}\right)\end{array}$ & $\begin{array}{l}897517.540^{\star} \\
\left(<0.001^{*}\right)\end{array}$ & $\begin{array}{l}1046.809^{*} \\
\left(<0.001^{\star}\right)\end{array}$ & $\begin{array}{l}1391.122^{*} \\
\left(<0.001^{\star}\right)\end{array}$ \\
\hline
\end{tabular}

Normally distributed data was expressed in Mean \pm SE.

F: F for ANOVA test, Pairwise comparison bet. each 2 groups were done using Post Hoc Test (Tukey)

$\mathrm{p}$ : $\mathrm{p}$ value for comparing between the studied groups

Means with Common letters are not significant (Means with Different letters are significant)

*: Statistically significant at $p \leq 0.05$

The inflammatory cytokines are expressed as $\mathrm{pg} / \mathrm{mg}$ protein.

Table (5): Effect of Apigenin on caspase-3 activities in testis and thyroid gland tissues of rats treated with lead acetate

\begin{tabular}{|c|c|c|c|}
\hline & \multirow[t]{2}{*}{ No. } & \multicolumn{2}{|l|}{$\begin{array}{l}\text { Caspase- } 3 \text { activities } \\
\text { (ng/mg protein) }\end{array}$} \\
\hline & & Testis & Thyroid grand \\
\hline Group I & 6 & $21.96^{c} \pm 0.10$ & $20.32^{c} \pm 0.14$ \\
\hline Group II & 6 & $56.90^{\mathrm{a}} \pm 0.40$ & $71.98^{\mathrm{a}} \pm 0.10$ \\
\hline Group III & 6 & $32.04^{b} \pm 0.13$ & $47.70^{b} \pm 0.13$ \\
\hline Group IV & 6 & $23.30^{c} \pm 0.09$ & $21.62^{c} \pm 0.12$ \\
\hline$F(p)$ & & $5490.826^{*}\left(<0.001^{\star}\right)$ & $37860.259^{\star}\left(<0.001^{\star}\right)$ \\
\hline
\end{tabular}

Normally distributed data was expressed in Mean \pm SE.

F: F for ANOVA test, Pairwise comparison bet. each 2 groups was done using Post Hoc Test (Tukey)

p: $p$ value for comparing between the studied groups

Means with Common letters are not significant (Means with Different letters are significant)

*: Statistically significant at $p \leq 0.05$

Table (6): Effect of Apigenin on some testicular and thyroid gland hormones in sera of rats treated with lead acetate 
No. Testicular hormones

Thyroid gland hormones

\begin{tabular}{|c|c|c|c|c|c|c|c|}
\hline & & $\begin{array}{l}\mathbf{T} \\
(\mathrm{pg} / \mathrm{ml})\end{array}$ & $\begin{array}{l}\text { LH } \\
(\mathrm{ng} / \mathrm{ml})\end{array}$ & $\begin{array}{l}\text { FSH } \\
(\mathrm{ng} / \mathrm{ml})\end{array}$ & $\begin{array}{l}\text { T3 } \\
\mathrm{pg} / \mathrm{dl}\end{array}$ & $\begin{array}{l}\mathrm{T4} \\
\mathrm{ng} / \mathrm{ml}\end{array}$ & $\begin{array}{l}\text { TSH } \\
\mu \mathrm{lU} / \mathrm{ml}\end{array}$ \\
\hline Group I & 6 & $8.52^{\mathrm{a}} \pm 0.12$ & $1.50^{\mathrm{a}} \pm 0.05$ & $0.87^{a} \pm 0.01$ & $121.8^{a} \pm 0.26$ & $9.42^{\mathrm{a}} \pm 0.08$ & $7.42^{b} \pm 0.07$ \\
\hline Group II & 6 & $4.71^{c} \pm 0.01$ & $0.69^{c} \pm 0.01$ & $0.26^{c} \pm 0.01$ & $55.30^{c} \pm 0.10$ & $3.37^{d} \pm 0.05$ & $10.46^{\mathrm{a}} \pm 0.07$ \\
\hline Group III & 6 & $6.28^{b} \pm 0.06$ & $0.9^{b} \pm 0.02$ & $0.57^{b} \pm 0.01$ & $97.2^{\mathrm{b}} \pm 0.37$ & $7.12^{\mathrm{a}} \pm 0.10$ & $5.38^{c} \pm 0.04$ \\
\hline Group IV & 6 & $8.32^{\mathrm{a}} \pm 0.09$ & 1. $4^{\mathrm{a}} \pm 0.0$ & $0.89^{a} \pm 0.0$ & $124^{\mathrm{a}} \pm 0.55$ & $9.34^{c} \pm 0.05$ & $7.38^{b} \pm 0.04$ \\
\hline$F(p)$ & & $\begin{array}{l}2572.732^{*} \\
\left(<0.001^{*}\right)\end{array}$ & $\begin{array}{l}171.819^{*} \\
\left(<0.001^{\star}\right)\end{array}$ & $\begin{array}{l}1719.320^{*} \\
\left(<0.001^{*}\right)\end{array}$ & $\begin{array}{l}7528.183^{*} \\
\left(<0.001^{*}\right)\end{array}$ & $\begin{array}{l}1488.571^{*} \\
\left(<0.001^{*}\right)\end{array}$ & $\begin{array}{l}975.458^{*} \\
\left(<0.001^{\star}\right)\end{array}$ \\
\hline
\end{tabular}

Normally distributed data was expressed in Mean $\pm \mathrm{SE}$.

F: F for ANOVA test, Pairwise comparison bet. each 2 groups was done using Post Hoc Test (Tukey)

$p: p$ value for comparing between the studied groups

Means with Common letters are not significant (Means with Different letters are significant)

*: Statistically significant at $p \leq 0.05$

Table (7): Effect of Apigenin on sperm parameters in rats treated with lead acetate

\begin{tabular}{lllll} 
& No. & Sperm & Motility \\
\cline { 3 - 4 } & & $\begin{array}{l}\text { Count } \\
\text { (million cells } / \mathrm{ml})\end{array}$ & $\begin{array}{l}\text { Abnormality } \\
(\%)\end{array}$ \\
\hline Group I & $\mathbf{5}$ & $95.4^{\mathrm{a}} \pm 0.8$ & $83.4^{\mathrm{a}} \pm 0.8$ & $8.0^{\mathrm{c}} \pm 0.4$ \\
\hline Group II & $\mathbf{5}$ & $62.4^{\mathrm{c}} \pm 0.7$ & $55.2^{\mathrm{c}} \pm 1.0$ & $43.2^{\mathrm{a}} \pm 1.0$ \\
\hline Group III & $\mathbf{5}$ & $75.0^{\mathrm{b}} \pm 1.0$ & $74.6^{\mathrm{b}} \pm 0.7$ & $21.8^{\mathrm{b}} \pm 0.7$ \\
\hline Group IV & $\mathbf{5}$ & $95.2^{\mathrm{a}} \pm 0.9$ & $85.2^{\mathrm{a}} \pm 0.8$ & $8.2^{\mathrm{c}} \pm 0.4$ \\
\hline F (p) & & $332.051^{*}\left(<0.001^{*}\right)$ & $269.60^{*}\left(<0.001^{*}\right)$ & $603.927^{*}\left(<0.001^{*}\right)$
\end{tabular}

Normally distributed data was expressed in Mean $\pm \mathrm{SE}$.

F: F for ANOVA test, Pairwise comparison bet. each 2 groups was done using Post Hoc Test (Tukey)

$p: p$ value for comparing between the studied groups

Means with Common letters are not significant (Means with Different letters are significant)

*: Statistically significant at $p \leq 0.05$

Figures 


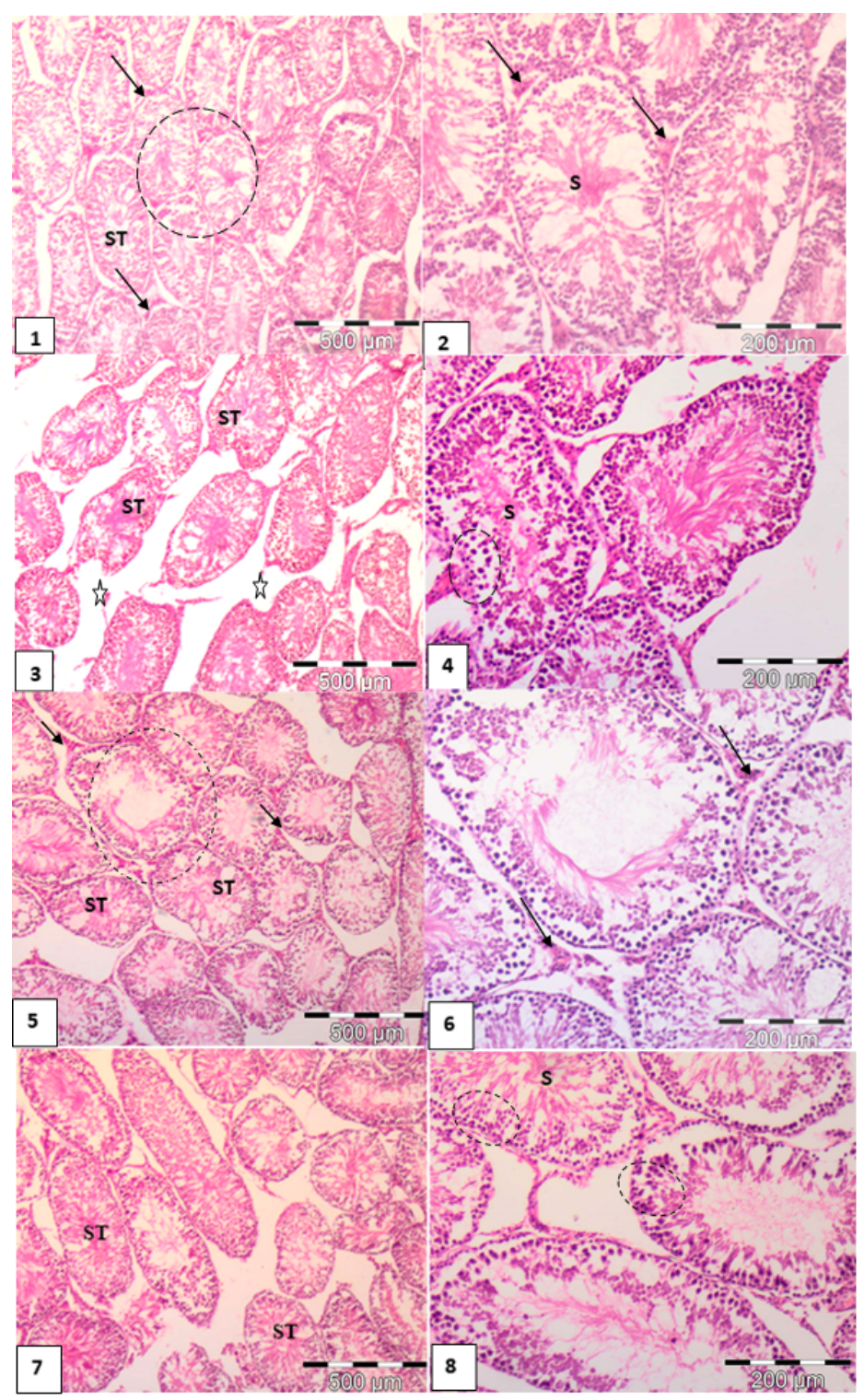

Figure 1

Please See the Supplemental Files section for the complete figure caption 